\title{
Water quality assessment of river Tons, Dehradun (Uttarakhand), India
}

\author{
Sangeeta M adan*, Shil pika Dutta and Chanchal \\ Department of Environmental Sciences, Kanya Gurukul Campus, Haridwar (Uttarakhand), INDIA \\ *Corresponding author: E-mail: n.madan79@yahoo.com \\ Received:October 7, 2012; Revised received: February 5,2013; Accepted:March 3, 2013
}

Abstract: Water quality of Tons river near Tapkeshwar temple in Dehradun was assessed in terms of their physicochemical parameters. Samples were collected on the monthly basis since January to March, 2011 from three sites viz confluence zone of temple, upstream and downstream river water. Total number of nine samples were analysed and a correlation matrices among parameters was determined. River water was showing alkaline character throughout the study period. $\mathrm{pH}$, alkalinity and chloride were found to be under the acceptable limit of BIS (2009), although turbidity and hardness were exceeding the limits at all three sites but total dissolved solid only on confluence zone and downstream river sites. Water samples from the confluence zone near the temple showed slightly higher concentration of all the parameters than other sites. The present study reveals the slight effects of various religious activities on confluence site of tons river water near the temple which were found to be under the prescribed permissible limits of BIS (2009).

Keywords: Confluence zone, Downstream, Tapkeshwar temple, Tons River, Upstream

\section{INTRODUCTION}

The Himalayan rivers have an important place in Indian culture and tradition. They are lifeline of majority of population in cities, towns and villages and are considered sacred (Semwal and Akolkar, 2006). Tons river is one of the most major perennial Indian Himalayan rivers originating from Bandar Punch mountain and an important tributary of Yamuna river. This river joins Yamuna at Kalsi in the North Western part of Dehradun valley, which is located $48 \mathrm{~km}$ away from Dehradun.

In India, lot of religious activities take place all round the year. Most of the temples and ritual places are located near the aquatic resources like pond, lakes and rivers etc. (Ujjania and Multani, 2011). In many cases, religion and culture are highly inter-twined and it is difficult to state whether a particular activity falls in the religious or cultural domain. The activities in which the river and/or its water plays a central role include taking a dip in the river on auspicious days, shaving the head of infant, cremation, shraddha ceremony etc. Apart from these, pilgrim offer milk, curd, ghee, flowers, coins, idols, ashes of departed ones, body hair and other religious materials into the water. Many a times such offerings are brought in polythene carry bags. In the absence of proper disposable system, the polythene bags are dropped in water or near the sites of water body. These polythene bags and other non-biodegradable materials remain either floating on the water surface or cover the river bed substratum, which is hazardous to aquatic life (CPCB, 2005).
The Tons river in Dehradun valley is also not untouched with these activities. Several religious activities are going on the bank of river in different temples. Therefore, an attempt has been made to study the water quality of Tons river passing through the Tapkeshwar temple in Dehradun.

\section{MATERIALS AND METHODS}

In order to conduct the present study, total numbers of thirty six samples were collected from three sites of Tons river near the Tapkeshwar temple in Dehradun from January to March, 2011. These three sites were designated as upstream $(25 \mathrm{~m}$. away before the confluence zone), downstream ( $25 \mathrm{~m}$. away after the confluence zone) and confluence zone (Fig.1). The confluence zone is the mixing zone of river and temple discards, elevated at $30^{\circ} 21^{\prime} 25.84^{\prime \prime} \mathrm{N}$ latitude and $78^{\circ} 01^{\prime} 00.45^{\prime \prime} \mathrm{E}$ longitude. The water quality was assessed in terms of their physico-chemical parameters like temperature, $\mathrm{pH}$, electrical conductivity, turbidity, total dissolved solid, free $\mathrm{CO}_{2}$, alkalinity, hardness, dissolved oxygen, biochemical oxygen demand and chloride referring the standard methods (APHA, 1995).

\section{RESULTS AND DISCUSSION}

The comparative study of upstream river water, confluence zone of temple and downstream river water has shown a significant difference in physico chemical properties. The monthly variation from January to March in water quality parameters are represented in Table 1 and their correlation in Tables 2, 3 and 4. All the 


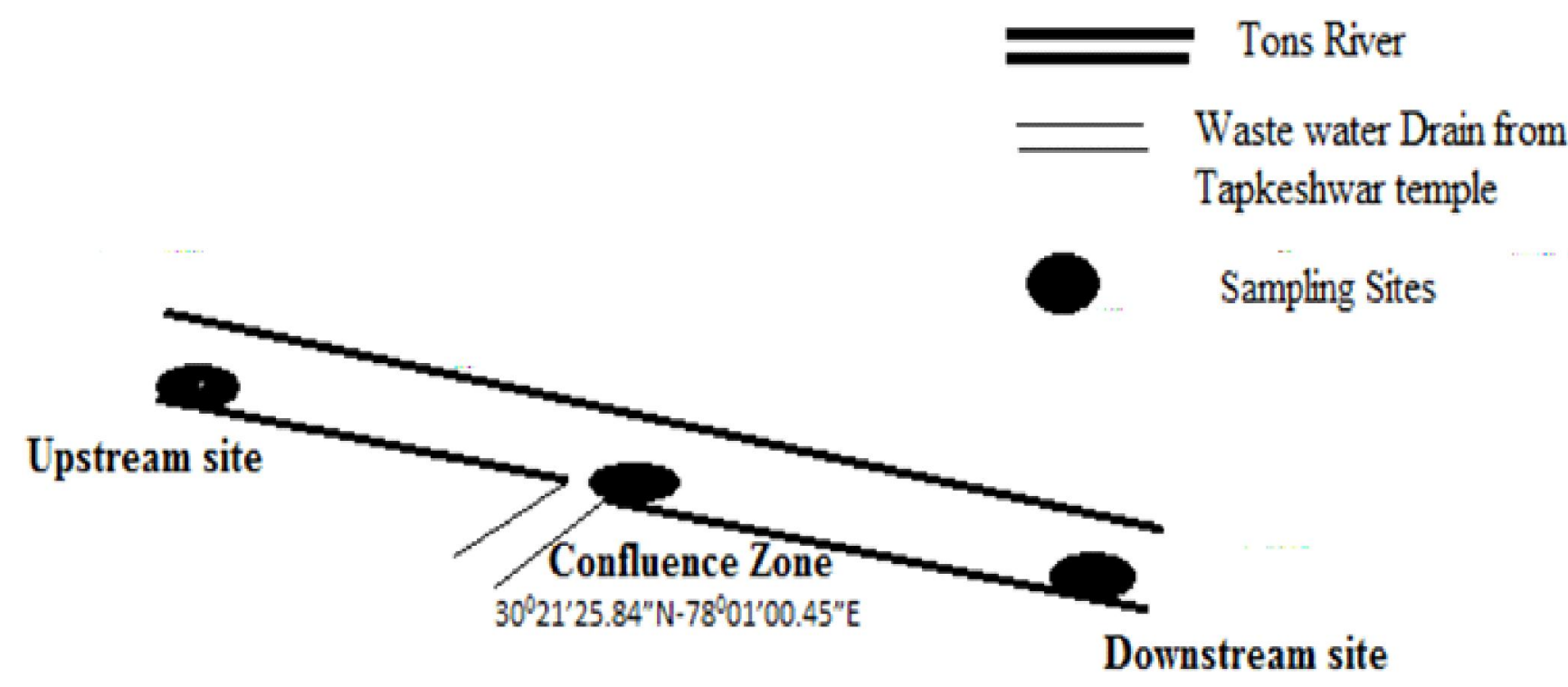

Fig.1. Showing sampling sites along Tons river near Tapkeshwar temple, D ehradun

parameters were found positively correlated with temperature except $\mathrm{pH}$ and dissolved oxygen.

Temperature is the most important physical property of surface water which determines its chemical properties. The temperature of confluence zone water is found comparatively higher than upstream and downstream river water. The rise in water temperature is responsible for increasing the chemical as well as biological reaction in water and reducing solubility of gases (Murugesan et al., 2004). At upstream site temperature of river water varied between $9.9^{\circ} \mathrm{C}$ to $12.5^{\circ} \mathrm{C}$, on confluence zone $12^{\circ} \mathrm{C}$ to $14.2^{\circ} \mathrm{C}$ and at downstream it was $10.2^{\circ} \mathrm{C}$ to $12.7^{\circ} \mathrm{C}$ with an average of $10.9 \pm 1.38^{\circ} \mathrm{C}, 13.23 \pm 1.12^{\circ} \mathrm{C}$ and $11.47 \pm 1.25^{\circ} \mathrm{C}$ respectively. Maximum temperature was observed on confluence zone site because the energy is added in water during work on confluence zone site by people (Garg, 2006).
According to Fakayode (2005), the $\mathrm{pH}$ of a water body is very important in determination of water quality since it affects other chemical reactions such as solubility and metal toxicity. The $\mathrm{pH}$ of river water was showing alkaline character throughout the study period at all three sites. The $\mathrm{pH}$ of river water at upstream site varied between 7.2 to 8.5 at confluence zone 7.1 to 8.2 and at downstream site 7.2 to 8.2 with an average of $7.87 \pm 0.65,7.67 \pm 0.55$ and $7.63 \pm 0.51$ respectively. $\mathrm{pH}$ is found to be negatively correlated with temperature and other parameters and positively correlated with DO River water shows alkaline $\mathrm{pH}$ throughout the study period, slightly decrease on confluence zone was observed due to addition and its decomposition of organic waste. Kumar et al. (2010) have also stated that the rivers Uttarakhand exhibit alkaline $\mathrm{pH}$ during the physical, chemical and bacteriological

Table 1. Physico chemical properties of Tons river near Tapkeshwar temple, Dehradun.

\begin{tabular}{lccccc}
\hline Parameters & Upstream & $\begin{array}{c}\text { Confluence } \\
\text { zone }\end{array}$ & Downstream & $\begin{array}{c}\text { BIS (2009) } \\
\text { Acceptable } \\
\text { limit }\end{array}$ & $\begin{array}{c}\text { BIS (2009) } \\
\text { Per missible } \\
\text { limit }\end{array}$ \\
\hline Temperature $\left({ }^{0} \mathrm{C}\right)$ & $10.93 \pm 1.38$ & $13.23 \pm 1.12$ & $11.47 \pm 1.25$ & - & - \\
pH & $7.87 \pm 0.65$ & $7.67 \pm 0.55$ & $7.63 \pm 0.51$ & $6.5-8.5$ & No Relaxation \\
E.C. $(\mathrm{mmhos} / \mathrm{cm})$ & $0.38 \pm 0.10$ & $0.46 \pm 0.20$ & $0.42 \pm 0.14$ & - & \\
Turbidity $(\mathrm{NTU})$ & $11.40 \pm 2.17$ & $16.22 \pm 3.85$ & $13.50 \pm 3.21$ & 1 & 5 \\
TDS $(\mathrm{mg} / \mathrm{l})$ & $425.33 \pm 300.14$ & $628.33 \pm 275.88$ & $730.00 \pm 251.59$ & 500 & 2000 \\
Free $\mathrm{CO}_{2}(\mathrm{mg} / \mathrm{l})$ & $4.27 \pm 1.55$ & $7.73 \pm 2.82$ & $5.70 \pm 2.19$ & - & - \\
Alkalinity $(\mathrm{mg} / \mathrm{l})$ & $176.67 \pm 25.17$ & $194.00 \pm 36.17$ & $176.67 \pm 30.55$ & 200 & 600 \\
Hardness $(\mathrm{mg} / \mathrm{l})$ & $515.00 \pm 110.34$ & $552.33 \pm 89.75$ & $514.00 \pm 106.15$ & 200 & 600 \\
D.O. $(\mathrm{mg} / \mathrm{l})$ & $10.36 \pm 2.10$ & $8.68 \pm 1.99$ & $8.17 \pm 0.55$ & - & - \\
BOD $(\mathrm{mg} / \mathrm{l})$ & $2.90 \pm 0.56$ & $3.70 \pm 0.98$ & $3.03 \pm 0.80$ & - & - \\
Chloride $(\mathrm{mg} / \mathrm{l})$ & $71.58 \pm 5.50$ & $91.25 \pm 6.60$ & $84.90 \pm 8.47$ & 250 & 1000 \\
\hline
\end{tabular}

Values are mean \pm S.D. of twelve observations each; E.C. $=$ Electrical conductivity, TDS= Total dissolved solid, DO= Dissolved oxygen, $\mathrm{BOD}=$ Biochemical oxygen demand 
study of their water

Electrical conductivity depends and increases with increase in ionic strength of water. Change in conductivity of sample may signal changes in mineral composition of raw water and intrusion of domestic water (Sayed and Gupta, 2010). At the site of upstream river, water showed a minimum value of electrical conductivity as $0.32 \mathrm{mmhos} / \mathrm{cm}$ and maximum value as $0.49 \mathrm{mmhos} /$ $\mathrm{cm}$ with an average value of $0.38+0.10 \mathrm{mmhos} / \mathrm{cm}$, at the site of confluence zone minimum was $0.33 \mathrm{mmhos} / \mathrm{cm}$, maximum was $0.69 \mathrm{mmhos} / \mathrm{cm}$ with average value of $0.46+0.20 \mathrm{mmhos} / \mathrm{cm}$ and at the site of downstream river water minimum and maximum value of electrical conductivity was recorded as $0.33 \mathrm{mmhos} / \mathrm{cm}$ and 0.58 mmhos/cm respectively with average value of $0.42 \pm 0.14$ $\mathrm{mmhos} / \mathrm{cm}$. Electrical conductivity was observed as highest on confluence zone due to higher temperature at this site because on increasing the temperature the ionization increases. Sayed and Gupta,(2010) have stated that electrical conductivity depends and increases with increase in ionic strength of water. Electrical conductivity is positively correlated with all parameters except $\mathrm{pH}$ and DO.

Water transparency is an important factor that controls the energy relationship at different trophic levels. It is essentially a function of reflection of light from the surface and is influenced by the absorption characteristics of both water and its dissolved and particulate matter (Stepane et al., 1959). The turbidity of water is inversely proportional to transparency. The turbidity of river water at upstream site was $8.92 \mathrm{NTU}$ as minimum and 12.92 NTU as maximum with an average of $11.40 \pm 2.17$ NTU, on confluence zone minimum was $12.04 \mathrm{NTU}$ and maximum was 19.63 NTU with an average of $16.22 \pm 3.85 \mathrm{NTU}$, at downstream site 9.9 NTU as minimum and 16.09 NTU as maximum was recorded with an average of $13.50 \pm 3.21$ NTU. Turbidity of river water was found maximum on confluence zone in comparison to other sites. Turbidity and TDS were also found positively correlated with all other parameters except $\mathrm{pH}$ and DO.

TDS values indicate the general nature of water quality and are usually related to conductivity. Water containing more than $500 \mathrm{mg} / \mathrm{l}$ of TDS is not considered desirable for drinking water supplies, though more highly mineralized water may be used where better quality water is not available (Jain, 2002). TDS of river water at upstream was varied between $120 \mathrm{mg} / \mathrm{l}$ to $720 \mathrm{mg} / \mathrm{l}$, at confluence zone $440 \mathrm{mg} / \mathrm{l}$ to $945 \mathrm{mg} / \mathrm{l}$ and at downstream it was 440 $\mathrm{mg} / \mathrm{l}$ to $890 \mathrm{mg} / \mathrm{l}$ with average value of $425.33+300.14 \mathrm{mg} /$ $1,628.33 \pm 275.88 \mathrm{mg} / \mathrm{l}$ and $730.00 \pm 251.59 \mathrm{mg} / \mathrm{l}$ respectively. Maximum value of TDS was observed on confluence zone and it was found to be positively correlated with temperature.

The free $\mathrm{CO}_{2}$ released by microbial activity is important for algal growth, as it is required for the photosynthesis (Ujjania and Multani, 2011). Free $\mathrm{CO}_{2}$ in river water at upstream site was varied between $2.5 \mathrm{mg} / \mathrm{l}$ to $5.4 \mathrm{mg} / \mathrm{l}$, on confluence zone $4.5 \mathrm{mg} / \mathrm{l}$ to $9.7 \mathrm{mg} / \mathrm{l}$ and at downstream it was $3.2 \mathrm{mg} / \mathrm{l}$ to $7.3 \mathrm{mg} / \mathrm{l}$ with average value of $4.27 \pm 1.55$ $\mathrm{mg} / \mathrm{l}, 7.73 \pm 2.82 \mathrm{mg} / \mathrm{l}$ and $5.70 \pm 2.19 \mathrm{mg} / \mathrm{l}$ respectively. An increase in free $\mathrm{CO}_{2}$ on confluence zone may be due to entry of organic and biodegradable waste pilgrims and their microbial decomposition that utilize oxygen for their respiration and release of $\mathrm{CO}_{2}$ in turn. Similar observation was also revealed by Bhatnagar and Sangwan, 2009. Free $\mathrm{CO}_{2}$ was positively correlated with temperature and negatively correlated with DO.

Total alkalinity is due to salts of weak acids and bicarbonates to highly alkaline water are unportable (Mahadev et al., 2010). High values of total alkalinity may be attributed to the increase in organic decomposition during which $\mathrm{CO}_{2}$ is liberated (Bharathi and Hosmani 1973). Alkalinity of river water at upstream site was recorded as $176.67 \pm 25.17 \mathrm{mg} / \mathrm{l}$ with minimum value of $150 \mathrm{mg} / \mathrm{l}$ and maximum value of $200 \mathrm{mg} / \mathrm{l}$, on confluence zone $194.00 \pm 36.17 \mathrm{mg} / \mathrm{l}$ with minimum as 160 $\mathrm{mg} / \mathrm{l}$ and maximum as $232 \mathrm{mg} / \mathrm{l}$ and at downstream it was $176.67 \pm 30.55 \mathrm{mg} / \mathrm{l}$ with minimum value of $150 \mathrm{mg} / \mathrm{l}$ and maximum of $210 \mathrm{mg} / \mathrm{l}$. Total hardness of water is due to the presence of bicarbonate, sulphate, chloride, and nitrates of $\mathrm{Ca}$ and $\mathrm{Mg}$ (Kumar et al. 2010). Total Hardness of river water at upstream site was recorded as $515.00 \pm 110.34 \mathrm{mg} / \mathrm{l}$ with minimum value of $400 \mathrm{mg} / \mathrm{l}$ and maximum value of $620 \mathrm{mg} / \mathrm{l}$, on confluence zone $552.33+89.75 \mathrm{mg} / \mathrm{l}$ with minimumas $470 \mathrm{mg} / \mathrm{l}$ and maximum as $648 \mathrm{mg} / \mathrm{l}$ and at downstream it was $514.00 \pm 106.15 \mathrm{mg} / \mathrm{l}$ with minimum value of $400 \mathrm{mg} / \mathrm{l}$ and maximum of $610 \mathrm{mg} / \mathrm{l}$. Total alkalinity and hardness were observed to be slightly increased on confluence zone dipping and dumping of substances through religious activity. Similar observation was also found by Bhatnagar and Sangwan, (2009); during the study of Brahmsarovar water quality in Kurukshetra. In the present study, alkalinity was found to be positively correlated with temperature.

DO is generally reduced in the water due to respiration of biota, decomposition of organic matter, rise in temperature, oxygen demanding wastes and inorganic reductant such as hydrogen sulphide, ammonia, nitrites, ferrous iron, etc. (Sahu et al., 2000). DO of river water at upstream site was recorded as $10.36 \pm 2.10 \mathrm{mg} / \mathrm{l}$ with minimum value of $9.1 \mathrm{mg} / \mathrm{l}$ and maximum value of 12.78 $\mathrm{mg} / \mathrm{l}$, on confluence zone $8.68+1.99 \mathrm{mg} / \mathrm{l}$ with minimum as $7.20 \mathrm{mg} / \mathrm{l}$ and maximum as $10.94 \mathrm{mg} / \mathrm{l}$ and at downstream it was $8.17 \pm 0.55 \mathrm{mg} / \mathrm{l}$ with minimum value of $7.6 \mathrm{mg} / \mathrm{l}$ and maximum of $8.7 \mathrm{mg} / \mathrm{l}$. DO showed reverse pattern on increasing the temperature because lower atmosphere hold less concentration of oxygen on increasing the temperature. Hence it was negatively correlated with 

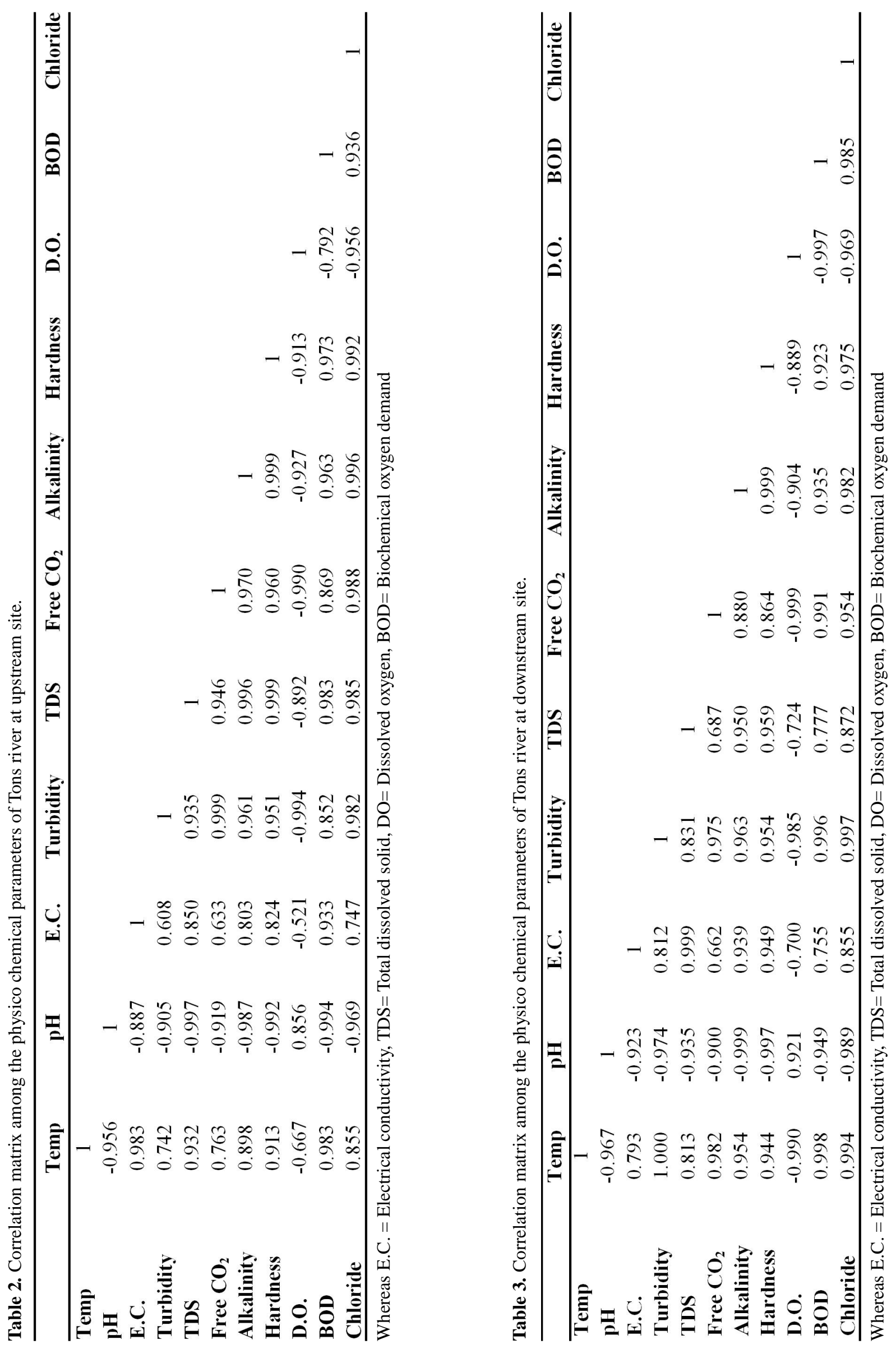


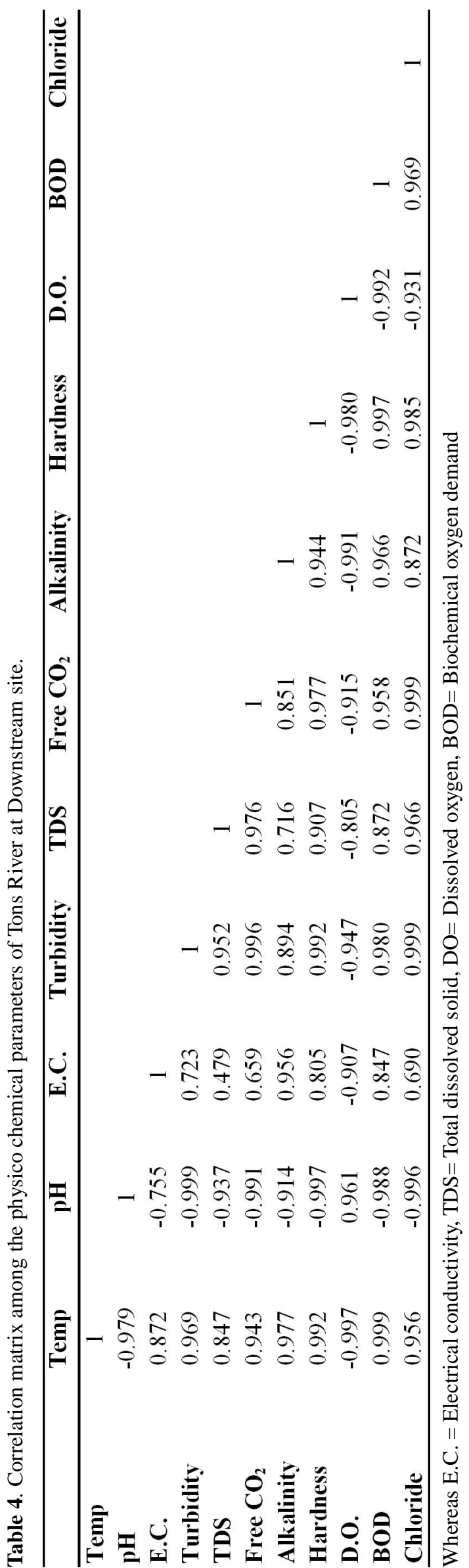

temperature and other parameters except $\mathrm{pH}$. Similar observation have also been found in the study of Khanna et al. (2010) who revealed the water quality characteristics of river Tons along the district Dehradun, Uttarakhand India.

BOD is a measure of the oxygen in the water that is required by the aerobic organisms. The biodegradation of organic materials exerts oxygen tension in the water and increases the biochemical oxygen demand (Abidaand Harikrishna, 2008). Biochemical Oxygen Demand of river water at upstream site was recorded as $2.90 \pm 0.56 \mathrm{mg} / \mathrm{l}$ with minimum value of $2.40 \mathrm{mg} / \mathrm{l}$ and maximum value of $3.50 \mathrm{mg} / \mathrm{l}$, on confluence zone $3.70 \pm 0.98$ $\mathrm{mg} / \mathrm{l}$ with minimum as $2.60 \mathrm{mg} / \mathrm{l}$ and maximum as $4.50 \mathrm{mg} /$ 1 and at downstream it was $3.03 \pm 0.80 \mathrm{mg} / \mathrm{l}$ with minimum value of $2.20 \mathrm{mg} / \mathrm{l}$ and maximum of $3.80 \mathrm{mg} / \mathrm{l}$. Chloride concentration in water indicates the presence of organic waste in water, primarily of animal origin (Thresh et al., 1949). Chloride of river water at upstream site was recorded as $71.58 \pm 5.50 \mathrm{mg} / \mathrm{l}$ with minimum value of $65.55 \mathrm{mg} / \mathrm{l}$ and maximum value of $76.32 \mathrm{mg} / \mathrm{l}$, on confluence zone $91.25 \pm 6.60 \mathrm{mg} / \mathrm{l}$ with minimum as $84.32 \mathrm{mg} / \mathrm{l}$ and maximum as $97.45 \mathrm{mg} / \mathrm{l}$ and at downstream it was $84.90 \pm 8.47 \mathrm{mg} / \mathrm{l}$ with minimum value of $75.31 \mathrm{mg} / \mathrm{l}$ and maximum of 91.39 $\mathrm{mg} / \mathrm{l}$.BOD and chloride was found maximum on confluence zone due to addition of organic waste. Both were positively correlated with temperature because on increasing temperature microbial activity and ionization increases resulting in increased concentration of BOD and chloride. Bhatnagar and Sangwan, 2009; had also reported that bathing and addition of ash increases chloride content of Brahmsarovar water in Kurukshetra

\section{Conclusion}

The present study revealed that the Tons river water is unpolluted near the Tapkeshwar temple because the physico chemical parameters analysed during the present assessment were found to be under the acceptable limits of BIS (2009) although hardness was slightly more than the acceptable limit at all three some sites and TDS on only confluence zone and downstream sites but found to be under the permissible limits. Only turbidity was found to be exceeding both the acceptable and permissible limits of BIS (2009). The river water was found to be alkaline throughout the study period. However, at confluence zone, water samples showed higher concentration of all parameters in comparison to other sampling sites.

\section{REFERENCES}

Abida, B. and Harikrishna (2008). Study on the Quality of Water in Some Streams of Cauvery River. E- J ournal of Chemistry, 5 (2): 377-384.

APHA (1995). Standard methods for examination of water and waste water $\left(19^{\text {th }}\right.$ edn $)$ American Public Health Association 
Washington, D.C.

Bharathi, S.G. and Hosmani, S.P. (1973). Hydrobiological studies in ponds and lakes of Dharwar (yemmekeri Pond). partl. Ibd., 18: 246-254.

Bhatnagar, A. and Sangwan, P. (2009). Impact of mass Bathing on Water Quality. Int. J. Environ. Res., 3(2): 247-252 spring.

CPCB, Delhi, (2005). Bio-mapping of perennial rivers of Assam. Parivesh Newsl.

Fakayode, S.O. (2005). Impact Assessment of Industrial Effluent on Water Quality of the Receiving ALaro River in Ibadan. Nigeria.Ajeam-Ragee, 10: 1-13.

Garg, S.K. (2006). Sewage Disposal and Air Pollution Engineering. K hanna Publishers. Eighteenth revised edition.

Jain, C.K. (2002). A hydro-chemical study of a mountainous watershed: the Ganga, India. Water Research, 36(5): 1262-1274.

Khanna, D.R., Bhutiani, R., Matta, G., Singh, V., Tyagi, P. and Ishaq, F. (2010). Water quality characteristics of river Tons at District-Dehradun, Uttarakhand (India). Environment Conservation J ournal 11(1\&2) 119-123.

Kumar, A., Bisht, B.S., Jhoshi, V.D., Singh, A.K. and Talwar, A. (2010). Physical, Chemical and Bacteriological study of water from Rivers of Uttarakhand. J H um E col, 32(3):169-173.

Kumar, A., Bisht, B.S., Talwar, A. and Chandel, D. (2010). Physico-chemical and microbial analysis of ground water from different regions of Doon Valley. Int. J ou. Appl. Env. Sci, 5(3): 433-440.

Mahadev, J., Hosamani, S.P. and Ahmed, S.A.(2010). Statistical multivariate analysis of lakes water quality parameters in
Mysore, Karnataka, India. World A pplied Sciences J ournal, 8(11): 1370-1380.

Murugesan, S., Kumar, D. S., Rajan, S., and Chandrika, D. 2004). Comparative study of ground water resources of east and west region of Chennai, Tamilnadu. Nat. Env. and Poll.Tech., 3(4): 495-499.

Sahu, B.K., Rao, R.J., Behara, S.K. and Pandit, R.K. (2000). Effect of pollutants on the dissolved oxygen concentration of the river Ganga at Kanpur. In: Pollution and biomonitoring of Indian rivers (Ed.: R.K. Trivedy). ABD Publication, Jaipur, India. pp. 168-170.

Sayed, R.A. and Gupta, S.G. (2010). River water quality assessment in Beed district of Maharashtra: Seasonal parametric variation. Iranica Journal of Energy and Environment, 1(4): 326-330.

Semwal, N. and Akolkar, P. (2006). Water quality assessment of sacred Himalayan Rivers of Uttaranchal. Current Science, 91(4): 486-496.

Stepane, K.M. (1959). Limnological Study of the reservoir sedlice near Zelive. IX. Transmission and Transparency of water. Sci. pap. Inst. Chem. Tedinol;Pragne. Fac-Technol Fuel Water, 3: 363-430.

Thresh J.C., Beale, J.F. and Suckling, E.V. (1949). The examination of water and water supplies (Ed.: E.W. Taylor). London.

Ujjania, N.C. and Multani, Azhar A. (2011). Impact of Ganesh Idol Immersion Activities on the Water Quality of Tapi River, Surat (Gujarat) India. Research J ournal of Biology, 1(1):11-15. 